\section{SOSIALISASI \\ PENGGUNAAN METODE \\ PEMBELAJARAN BLENDED \\ LEARNING DI MASA \\ PANDEMI BAGI GURU DI MA ALKAHFI BOGOR}

\author{
Maya Nurfitriyanti', Fatwa Patimah \\ Nursa'adah ${ }^{2}$, Aulia Masruroh ${ }^{3}$ \\ I, 2, 3 Universitas Indraprasta PGRI \\ *Maya Nurfitriyanti \\ Email : maya_fitri31@yahoo.co.id
}

\begin{abstract}
The Covid-19 pandemic has forced us to make habits that we never imagined before. This also triggers changes in the learning system from primary education to higher education. One of the changes in the education system is the distance learning system (PJJ). In this condition, teachers must quickly adjust the new policies issued by the government, namely by learning activities and teaching students from home to prevent the spread of COVID-19. One of the efforts to do so that learning runs effectively is the blended learning method. Blended learning combines computer and internet technology offered by online learning and faceto-face learning participation to provide the most effective and efficient experience. Using the correct learning methods, overcoming learning obstacles due to COVID-I 9 can be overcome. With the blended learning method, students learn independently, and teachers can continue to explain the subject matter using learning media such as the internet.
\end{abstract}

Keywords: blended learning; covid pandemic

\begin{abstract}
Abstrak
Pandemi Covid-19 sudah memaksa kita melakukan kebiasan yang tidak pernah kita banyangkan sebelumnya. Hal ini juga memicu terjadinya perubahan sistem pembelajaran dari mulai dunia pendidikan dasar sampai pendidikan tingkat akhir yaitu perguruan tinggi. Salah satu perubahan yang terjadi dalam system Pendidikan yaitu sistem pembelajaran jarak jauh (PJJ). Pada kondisi ini, guru diharuskan dengan cepat menyesuaikan kebijakan baru yang dikeluarkan pemerintah yaitu dengan kegiatan belajar dan membelajarkan peserta didik dari rumah demi pencegahan penyebaran covid-19. Banyak cara atau usaha pendidik yang dapat dilakukan pendidik agar pembelajaran tetap berjalan efektif yaitu salah satunya dengan menggunakan metode pembelajaran blended learning. Blended learning merupakan metode pembalajaran yang menggunakanperpaduan pemanfaatan teknologi komputer dan internet yang digunakan saat pembelajaran online dengan pembelajaran yang dilakukan secara tatap muka sehingga diharapkan dapat memberikan pengalaman belajar yang lebih efektif dan efisien. Dengan menggunakan metode pembelajaran yang tepat maka kendala pembelajaran akibat covid - 19 dapat diatasi. Dengan medote pembelajaran blended learning, peserta didik tidak hanya belajar secara mandiri, melainkan juga guru dapat tetap menjelaskan materi pelajaran menggunakan perpaduan dari media pembelajaran seperti internet.
\end{abstract}

Kata Kunci: blended learning; pandemi covid 
Sosialisasi Penggunaan Metode Pembelajaran Blended Learning di Masa Pandemi bagi Guru di MA Alkahfi Bogor

Maya Nurfitriyanti, Fatwa Patimah Nursa'adah, Aulia Masruroh

Volume 1, No. 3, Desember 2021 hal. 202- 209

DOI Artikel: 10.46306/jub.v1i3.37

\section{PENDAHULUAN}

Pandemi Covid-19 sudah memaksa kita melakukan kebiasan yang tidak pernah kita banyangkan sebelumnya. Hal ini juga memicu terjadinya perubahan sistem pembelajaran di dunia pendidikan dasar sampai perguruan tinggi yang tadinya tatap muka secara langsung di ruangan atau di dalam kelas menjadi sistem pembelajaran di dalam jaringan atau pembelajaran yang terpisah secara geografis antara pendidik dan peserta didiknya. Pembelajaran yang semula tatap muka di kelas berubah menjadi tatap maya atau dalam jaringan (daring). Wahono dalam (Hakim et al., 202I)menyatakan bahwa sejak merebaknya virus covid 19, pada tahun ajaran baru dibulan Juli 2020, Kementrian Pendidikan dan Kebudayaan melakukan transformasi kegiatan pembelajaran dari luring menjadi daring. Hal ini menjadi tantangan bagi pihak penyelenggara pendidikan dalam hal ini sekolah, peserta didik, dan orang tua dimana diperlukan persiapan berupakesiapan infrastruktur Internet, pengetahuan menggunakan alat teknologi komunikasi, dan lain sebagainya.

Menurut Imania \& Bariah (2019) pembelajaran daring merupakan bentuk penyampaian pembelajaran konvensional yang dituangkan pada format digital melalui internet. Dalam hal ini, seluruh civitas akademika terutama guru harus bekerja keras untuk mempersiapkan pembelajaran daring. Kebijakan pembelajaran daring ini didasarkan pada Surat Edaran (SE) pemerintah melalui Menteri Pendidikan dan Kebudayaan dengan Nomor 36962/MPK.A/HK/2020 tanggal 17 Maret 2020 tentang: Pembelajaran secara daring dan bekerja dari rumah dalam rangka Pencegahan Penyebaran Covid- 19.

Guru merupakan garda terdepan dalam pendidikan. Guru diharuskan dengan cepat menyesuaikan kebijakan baru yang dikeluarkan pemerintah dengan kegiatan belajar dan membelajarkan siswa dari rumah demi pencegahan penyebaran covid-19. Banyak usaha yang dapat dilakukan yang dapat dilakukan untuk tetap membelajarkan peserta didik dari rumah salah satunya yaitu dengan diterapkannya metode pembelajaran yang efektif dan tepat. Sung dkk dalam (Oktaviani et al., 202I) menyatakan bahwa variasi penggunaan media pembelajaran dalam proses belajar mengajar memiliki beberapa manfaat yaitu: (I) Pengajaran lebih menarik perhatian sehingga motivasi belajar peserta didik tumbuh, (2) Bahan pengajaran lebih jelas sehingga peserta didik memahami dan menguasai tujuan pengajaran dengan baik, (3) Metode mengajar lebih bervariasi, (4) Peserta didik lebih banyak melakukan interaksi dalam kegiatan belajar karena peserta didik melakukan aktivitas lain seperti mengamati, dan mendemonstrasikan.

Madrasah Aliyah Al-Kahfi merupakan salah satu sekolah yang juga terdampak pandemic Covid. Madrasah Aliyah Al Kahfi berada di Kawasan Cigombong, Bogor, Jawa Barat. Madrasah Aliyah Al Kahfi merupakan sekolah yang terakreditasi A di bawah kepemimpinan Bapak. Agus Khoirul Anwar, Lc. Dikarenakan kondisi ini, maka pembelajaran yang dilaksanakan di Madrasah Aliyah Al-Kahfi ini dilakukan secara daring. Namun sayangnya pelaksanaan pembelajaran daring saat ini belum maksimal. Hal ini dikarenakan peserta didik di tuntut untuk melaksanakan pembelajaran secara online dan mandiri tanpa ada tatap muka dengan guru.

Dikarenakan keadaan pandemi yang memaksakan tidak adanya interaksi antara peserta didik dan guru, peserta didik yang satu dengan peserta didik yang lainnya, guru merasa kesulitan dalam hal pemilihan 
Sosialisasi Penggunaan Metode Pembelajaran Blended Learning di Masa Pandemi bagi Guru di MA Alkahfi Bogor

Maya Nurfitriyanti, Fatwa Patimah Nursa'adah, Aulia Masruroh

Volume 1, No. 3, Desember 2021 hal. 202- 209

DOI Artikel: 10.46306/jub.v1i3.37

metode yang baik yang bias diterapkan untuk pembelajaran jarak jauh (PJJ). Oleh sebab itu diperlukan metode pembelajaran khusus yang efektif untuk peserta didik dan juga tetap membantu pemerintah dalam menangani pandemi ini. Salah satu metode pembelajaran yang efektif untuk dilaksanakan saat kondisi pandemi ini adalah metode pembelajaran blended leraning.

Fahyuni (2017)menjelaskan bahwa blended merupakan campuran atau kombinasi yang baik, sedangkan learningmerupakan belajar, dengan demikian blended learning dapat diartikan sebagai pola pembelajaran yang mengandung unsur pencampuran, atau penggabungan antara satu pola dengan pola yang lainnya. Kombinasi itulah yang dapatmembentuk pola pembelajaran yang efisien dan efektif. Pola tersebut dapat berupa perpaduan pembelajaran daring maupun pembelajaran tatap muka.

Kurtus dalam (Istiningsih \& Hasbullah, 2015)menyatakan bahwa "blended learning is a mixture of the various learning strategies and delivery methods that will optimize the learning experience of the user". Blended learningmerupakan campuran dari berbagai strategi pembelajaran dan metode penyampaian yang akan mengoptimalkan pengalaman belajar bagi penggunanya. Strategi pembelajaran yang dimaksud dapat berupa media pembelajaran yang digunakan seperti internet dan video. Hal tersebut sejalan dengan pendapat MacDonald dalam (Sudarman, 2020)yang menyatakan bahwa blended learning biasanya berasosiasi dengan memasukkan media online pada program pembelajaran. Pada saat yang sama tetap memperhatikan adanya pembelajaran tatap muka dan pendekatan konvensional yang lain untuk mendukung peserta didik.

Kebanyakan guru disekolah yang melaksanakan pembelajaran online penuh tanpa penjadwalan untuk tatap muka. Begitu juga di Madrasah Aliyah Al Kahfi, pembelajaran keseluruhan dilaksanakan secara daring tanpa adanya kombinasi tatap muka. Hal ini dikarenakan masih banyak guru yang belum memahami mengenai metode pembelajaran blended learning. Berdasarkan hal ini diperlukan sosialisasi dan penyuluhan mengenai pengguanaan metode pembelajaran blended learning yang bisa digunakan sekolah di masa pandemi. Salah satu kegiatan yang dilaksanakan yaitu "PKM Sosialisasi Penggunaan Metode Pembelajaran Blended Learning di Masa Pandemi”. Dengan adanya kegiatan PKM ini, diharapkan mampu memberikan solusi yang tepat terhadap pemilihan dan penggunaan metode pembelajaran yang bias digunakan pada masa pandemi.

\section{METODE PENGABDIAN}

Kegiatan ini dilaksanakan di Madrasah Aliyah Alkahfi. Kegiatan pengabdian masyarakat ini dilaksanakan mulai dari bulan maret sampai dengan bulan Agustus 2021. Kegiatan ini menggunakan konsep pelatihan secara daring, dimana peserta diberikan pembekalan dan materi dengan nuansa riang gembira. Pembekalan tersebut diharapkan menghasilkan peserta berkualitas. Sehingga pada akhirnya peserta pelatihan mampu mengaplikasikan apa yang telah diperoleh dari penyuluhan dan pelatihan tersebut berupa sesuatu yang berharga dan bernilai. Adapun tahap pelakasanaan kegiatan ini adalah sebagai berikut: 
Sosialisasi Penggunaan Metode Pembelajaran Blended Learning di Masa Pandemi bagi Guru di MA Alkahfi Bogor

Maya Nurfitriyanti, Fatwa Patimah Nursa'adah, Aulia Masruroh

Volume 1, No. 3, Desember 2021 hal. 202- 209

DOI Artikel: 10.46306/jub.v1i3.37

I. Pendahuluan

Tahap pendahuluan ini menggunakan metode observasi. Dengan menggunakan metode ini diharapkan tim mendapatkan informasi tentang metode pembelajaran yang diterapkan guru di lingkungan Madrasah Aliyah Alkahfi pada masa pandemi. Metode ini diperoleh data bahwa pembelajaran yang digunakan oleh guru di sekolah belum mampu menangani permasalahan pembelajaran pada masa pandemi.

2. Sosialisasi

Tahap sosialisasi dilakukan dengan cara diskusi dari tim abdimas dengan kepala sekolah, dan guru Madrasah Aliyah Alkahfi. Diskusi ini membahas mengenai solusi dari permasalahan-permasalahan yang muncul di sekolah mengenai metode pembelajaran pada masa pandemi. Hasil dari diskusi yang dilakukan yaitu dengan diperolehnya solusi untuk pengembangan metode pembelajaran yangakan dilaksanakan di Madrasah Aliyah Alkahfi pada masa pandemi.

3. Pelaksanaan

Tahap ini dilakukan penyuluhan mengenai Pendidikan karakter di sekolah kepada guru-guru dan pihak sekolah di Madrasah Aliyah Alkahfi. Pelaksanaan pelatihan ini akan dilakukan secara online melalui Zoom Cloud Meeting.

\section{PELAKSANAAN DAN PEMBAHASAN}

Metode pembelajaran Blended learning merupakan gabungan 2 istilah Bahasa Inggris, yaitu: blended dan learning. Kata blend artinya campuran, sedangkan learn artinya belajar. Secara sederhana blended learning dapat dimaknai dengan belajar campuran. Oleh karenanya, metode pembelajaran ini mengunakan perpaduan berbagai macam cara. Istilah blended learning disepakati oleh para ahli merupakan perpaduan pembelajaran secara konvensional dan daring. Pembelajaran blended learning dipilih karena menjadi satu-satunya media penyampaian materi antara guru dan siswa dalam masa darurat pandemi. Menurut Prayitno (2015)blended learning merupakan penggabungan aspek terbaik dari pembelajaran daring, aktivitas tatap muka terstruktur, dan praktik nyata.

Karakteristik pembelajaran menggunakan blended learning yaitu: I) pembelajaran yang menggabungkan berbagai cara penyampaian, gaya pembelajaran,model pendidikan, dan beragam media berbasis teknologi; 2) sebagai kombinasi pendidikan langsung (face to face), belajar mandiri, dan belajar secara mandiri secara online; 3) pembelajaran yang didukung oleh kombinasi efektif dari cara penyampaian, pengajaran, dan gaya pembelajaran; 4) pendidik dan orang tua memiliki peranan yang sama pentingnya, dimana pendidik sebagai fasilitator, dan orang tua sebagai pendukung (Prayitno, 2015).

Program ini dilaksanakan secara virtual menggunakan zoom pada tanggal 03 April 202I di MA Al Kahfi Bogor. Program pengabdian masyarakat berupa penyuluhan sosialisasi penggunaan metode pembelajaran blended learning di masa pandemi. Pembahasan pada pengabdian masyarakat ini yaitu metode 
Sosialisasi Penggunaan Metode Pembelajaran Blended Learning di Masa Pandemi bagi Guru di MA Alkahfi Bogor

Maya Nurfitriyanti, Fatwa Patimah Nursa'adah, Aulia Masruroh

Volume 1, No. 3, Desember 2021 hal. 202- 209

DOI Artikel: 10.46306/jub.v1i3.37

pembelajaran blended learning, serta hal yang diperhatikan dalam pembelajaran blended learning. Tujuan pengabdian masyarakat ini yaitu menambah wawasan guru dan pihak sekolah agar bisa menggunakan metode pembelajaran blended learning di masa pandemi. Harapan dari pengabdian masyarakat adalah memberikan solusi yang terbaik terhadap pembelajaran di masa pandemi sehingga peserta didik dapat mengembangkan keterampilan yang dimilikinya. Penyuluhan metode blended learning dalam pembelajaran banyak guru-guru yang belum memahami tentang kegunaan metode blended learning dalam pembelajaran di Sekolah. Penggunaan metode pembelajaran di MA AL Kahfi Bogor saat kondisi pandemi ini masih kurang efektif. Padahal sarana prasarana yang ada di Sekolah ini cukup memadai dan mendukung.

Kegiatan abdimas ini dilaksanakan secara virtual menggunakan aplikasi zoom yaitu tanggal 03 April 2021 .

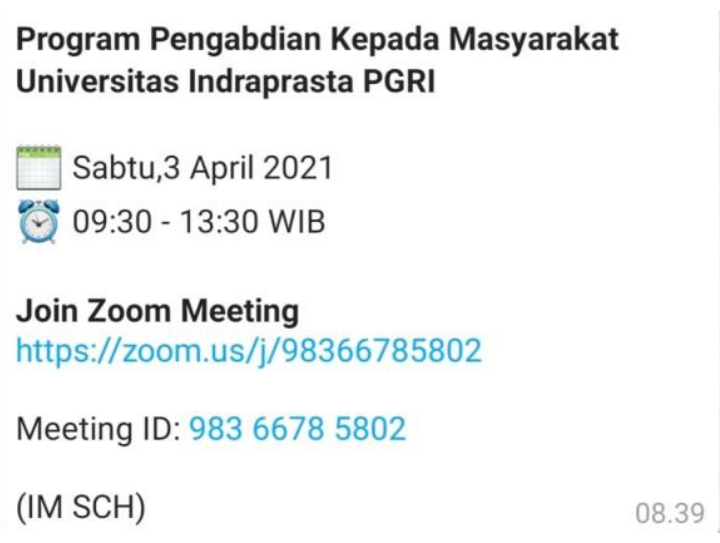

Gambar I. Undangan Via Zoom

Realisasi kegiatan dilakukan tiga tahap yaitu tahap persiapan, pelaksanaan, dan evaluasi. Tahap kesatu yaitu tahap persiapan, tahap ini tim mensurvey tempat lokasi pada tanggal 02 Maret 202I untuk menganalisis kondisi tempat, kondisi peserta, dan menyusun rancangan kegiatan. Selanjutnya tim abdimas mempersiapkan materi presentasi, sarana prasarana seperti laptop. Tahap selanjutnya yaitu tahap pelaksanan. Tahap pelaksanaan dilaksanakan pada tanggal 03 April 202I. Tahap ini tim melakukan penyuluhan materi tentang sosialiasasi metode pembelajaran blended learning di masa pandemi. 
Sosialisasi Penggunaan Metode Pembelajaran Blended Learning di Masa Pandemi bagi Guru di MA Alkahfi Bogor

Maya Nurfitriyanti, Fatwa Patimah Nursa'adah, Aulia Masruroh

Volume 1, No. 3, Desember 2021 hal. 202- 209

DOI Artikel: 10.46306/jub.v1i3.37

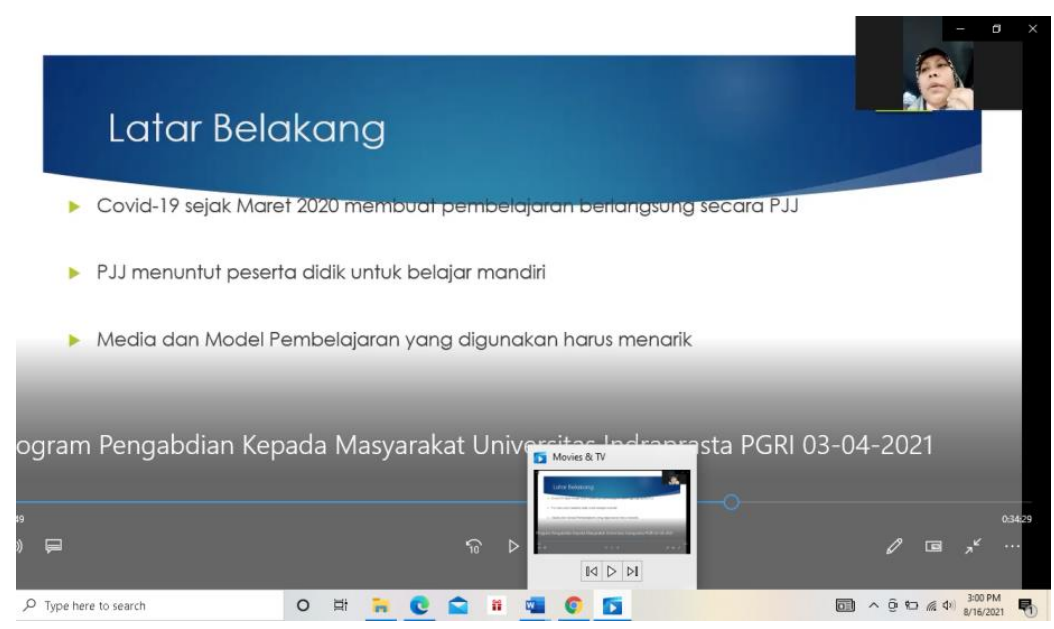

Gambar 2. Pelaksanaan Sosialisasi Metode Pembelajaran Blended Learning Oleh Pemateri

Peserta diberikan pengetahuan tentang apa itu metode pembelajaran blended learning, pembelajaran daring dengan menggunakan metode blended. Peserta penyuluhan adalah semua guru di MA AI Kahfi Bogor sebanyak 16 orang. Kegiatan dimulai dengan presentasi tentang sosialisasi pembelajaran dengan menggunakan metode blended learning di masa pandemi. Selama acara berlangsung peserta sangat semangat mengikuti acara ini dikarenakan ini pertama kali nya peserta menerima materi tentang metode blended learning di masa pandemi. Tahap berikutnya yaitu tahap evaluasi. Tahap evaluasi peserta mengajukan pertanyaan tentang metode blended learning di masa pandemi. Tahap ini tim menelaah acara ini selama penyuluhan berlangsung. Secara keseluruhan dalam pelaksanaan tidak ada hambatan. Peserta merasakan pengalaman yang berbeda, karena dapat mengetahui dan mempraktekkan metode blended learning dalam pembelajaran.

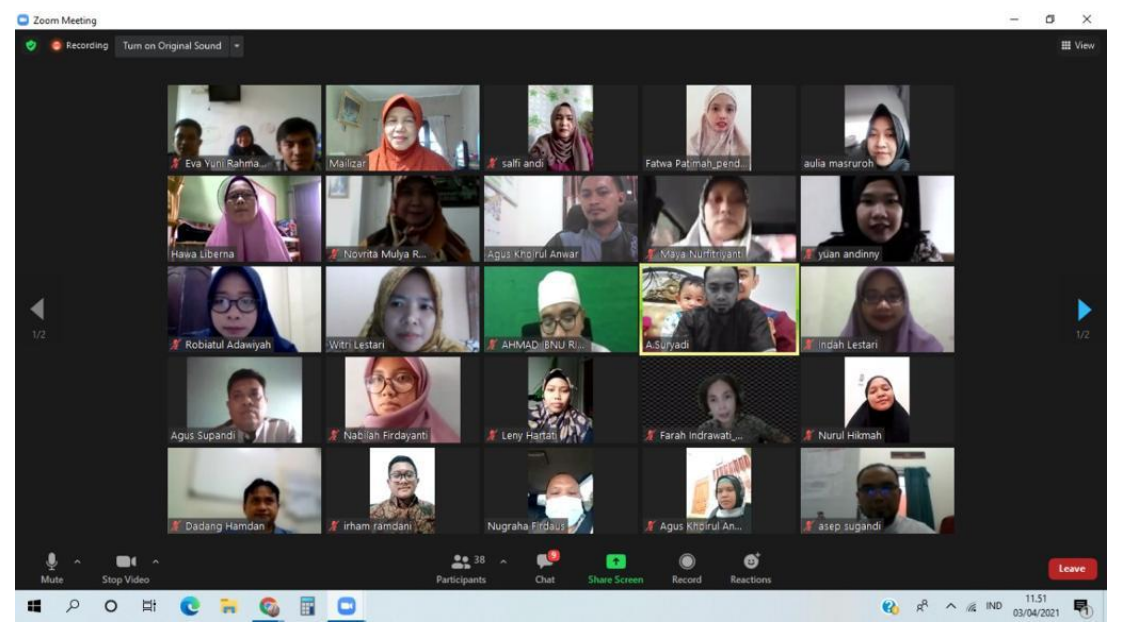

Gambar 3. Sesi Tanya Jawab Antara Pemateri dengan Guru MA AI Kahfi 
Sosialisasi Penggunaan Metode Pembelajaran Blended Learning di Masa Pandemi bagi Guru di MA Alkahfi Bogor

Maya Nurfitriyanti, Fatwa Patimah Nursa'adah, Aulia Masruroh

Volume 1, No. 3, Desember 2021 hal. 202- 209

DOI Artikel: 10.46306/jub.v1i3.37

Manfaat pembelajaran daring dengan metode blended learning sangat dirasakan oleh kedua pihak baik peserta didik maupun tenaga pengajar. Bagi peserta didik, pembelajaran daring merupakan salah satu metode alternatif belajar yang tidak menuntut peserta didik untuk hadir di kelas. Pembelajaran daring membentukpeserta didik berpikir secara kognitif dan mengembangkan keterampilan dalam belajar materi tertentu. Sedangkan bagi tenaga pengajar, metode pembelajaran daring hadir untuk mengganti gaya mengajar konvensional yang secara tidak langsung akan berdampak pada profesionalitas kerja. Model pembelajaran daring juga memberi kesempatan bagi guru untuk menilai dan mengevaluasi kemajuan belajar siswa secara lebih efisien. Ternyata, metode pembelajaran daring ini mendorong konsep blended learning antara online dan offline (luar jaringan) yang direncanakan oleh pemerintah. Konsep blended learning bertujuan untuk memberikan fleksibilitas pembelajaran yang belum pernah dirasakan peserta didik sebelumnya. Peserta didik mempunyai kesempatan untuk mengeksplorasi belajar daring secara luas sesuai minatnya, tetapi juga mendapatkan kesempatan untuk mengembangkan kebutuhan dan keterampilan sosial lewat pertemuan luring dengan guru dan teman.

Kesuksesan dalam pelaksanaan pengabdian masyarakat dilihat dari kehadiran peserta, peserta yang hadir sebanyak 16 orang (100\%). Hal ini didukung kepala sekolah dan guru-guru dari persiapan dan penyedian tempat. Tujuan pelatihan dapat dikatakan baik dan berhasil (80\%) dilihat dari guru-guru di MA AI Kahfi memahami metode blended learning dalam pembelajaran di Sekolah. Target materi yang telah direncanakan dapat dikatakan baik (80\%) dilihat dari semua materi pelatihan dapat disampaikan secara keseluruhan. Materi penyuluhan yang disampaikan adalah bagaimana metode blended learning di sekolah dan apa saja yang perlu diperhatikan dalam metode blended learning. Kemampuan peserta dalam penguasaan materi dapat dikatakan baik $(80 \%)$ hal ini dikarenakan narasumber menjelaskan dengan jelas dan rinci. Secara keseluruhan kegiatan penyuluhan ini berhasil. Keberhasilan ini selain diukur dari keempat komponen juga dilihat dari kepuasaan peserta setelah mengikuti kegiatan penyuluhan. Manfaat yang dapat diperoleh para peserta penyuluhan adalah memahami tentang metode pembelajaran blended learning di masa pandemi.

\section{KESIMPULAN DAN SARAN}

Pengabdian masyarakat yang dilakukan di MA Al Kahfi Bogor berjalan dengan baik dan lancar. Mitra dalam hal ini kepala sekolah dan guru antusias mengikuti kegiatan demi kegiatan yang diberikan oleh tim pengabdi. Kegiatan pengabdian ini mendapat hasil yang positif, yaitu dengan terlihat dariminat tinggi yang diberikan guru kepada tim dikarenakan ini merupakan hal yang baru pertama kali dilaksanakan disekolah tersebut. Produk yang dihasilkan guru yaitu guru termotivasi untuk menggunakan metode blended learning dalam proses pembelajaran. Mengingat pentingnya kegiatan ini maka diperlukan kegiatan penyuluhan lain yang sejenis perlu dilaksanakan secara berkelanjutan, sunguh-sungguh dengan mengikut sertakan lebih banyak peserta dan pihak yang lebih berkompeten dibidangnya seperti Dinas Pendidikan, LPMP, Perguruan Tinggi secara bersama-sama. 
Sosialisasi Penggunaan Metode Pembelajaran Blended Learning di Masa Pandemi bagi Guru di MA Alkahfi Bogor

Maya Nurfitriyanti, Fatwa Patimah Nursa'adah, Aulia Masruroh

Volume 1, No. 3, Desember 2021 hal. 202- 209

DOI Artikel: 10.46306/jub.v1i3.37

\section{UCAPAN TERIMA KASIH}

Kegiatan pengabdian masyarakat telah berjalan dengan lancer dan baik. Oleh karena itu, kami dari tim mengucapkan terima kasih kepada warga sekolah Aliyah Al Kahfi Bogor khususnya kepada Kepala Madrasah, Ketua Program Studi Pendidikan Matematika Universitas Indraprasta PGRI serta Kepala Pusat Pengabdian kepada Masyarakat LPPM UNINDRA.

\section{DAFTAR PUSTAKA}

Fahyuni, E. F. (20I7). TEKNOLOGI, INFORMASI DAN KOMUNIKASI (PRINSIP DAN APLIKASI DALAM STUDI PEMIKIRAN ISLAM) (S. B. Sartika (ed.); I st ed., Vol. I). UMSIDA Press.

Hakim, T. D., Amelia, V., \& Monika, W. (202I). Pkm Penyuluhan Internet Sehat Di Smk Telkom Pekanbaru. Jubaedah : Jurnal Pengabdian Dan Edukasi Sekolah (Indonesian Journal of Community Services and School Education), I(I), 5I-59. https://doi.org/I0.46306/jub.vlil.I0

Imania, K. A., \& Bariah, S. K. (2019). Rancangan Pengembangan Instrumen Penilaian Pembelajaran Berbasis Daring. Jurnal Petik, 5(I), 3 I-47. https://doi.org/I0.3 I980/jpetik.v5il .445

Istiningsih, S., \& Hasbullah, H. (2015). Blended Learning, Trend Strategi Pembelajaran Matematika Masa Depan. Jurnal Elemen, I(I), 49-56.

Oktaviani, I., Rini, I. A., Ulfah, M. M., \& Andriana, A. D. (202I). Pengenalan Media Pembelajaran Daring Berbasis Stem Untuk Guru Ipa Di Sman 9 Bandar Lampung. Jubaedah: Jurnal Pengabdian Dan Edukasi Sekolah (Indonesian Journal of Community Services and School Education), I(I), 77-88. https://doi.org/l0.46306/jub.vlil.16

Prayitno, W. (20I5). Implementasi Blended Learning dalam Pembelajaran pada Pendidikan Dasar dan Menengah. Artikel LPMP D.I. Yogyakarta, I-I4. file://E:/Matematika/TUGAS NEGARA/Proposal/ref/Blended-Learning_Wendhie.pdf

Sudarman. (2020). IMPLEMENTASI PEMBELAJARAN DARING DENGAN MENGGUNAKAN MULAWARMAN ONLINE LEARNING. In W. D. Dwiyogo (Ed.), PEMBELAJARAN DI MASA COVID19 WORK FROM HOME (pp. 262-27I). Wineka Media. 